\title{
UJI DAYA HAMBAT BEBERAPA JENIS OBAT ANTIJAMUR PADA JAMUR YANG DI ISOLASI DARI KUKU KAKI
}

\author{
Inhibitiveness Test Of Several Types Of Antifungal Medication In Fungi Is Isolated \\ From Toenails
}

Ayu Minarni ${ }^{1}$, Widarti ${ }^{2}$, Rahman $^{2}$

Politeknik Kesehatan Kemenkes Jurusan Analis Kesehatan, Makassar

Koresponden: ayuminarni35@gmail.com/082354040094

\begin{abstract}
Nails are plates made of horn cells that cover the dorsal surface of the fingers and toes. Fungi are one of the normal floras. Fungi that are included in normal flora that infect nails are a class of dermatophytes such as Epidermaphyton floccosum. The aims of this research were to determine the inhibitory test of antifungal drugs from the azole group, namely antifungal drugs such as griseofulvin, ketoconazole, itraconazole, and clotrimazole. The type of research used is descriptive research conducted in the laboratory through observational antifungal inhibition power isolated from toenails. This research was conducted at the Makassar Health Polytechnic Microbiology Laboratory with a total sample of 10 samples. The results showed that the inhibitory test of several types of antifungal did not occur in the fungi isolated from toenails, therefore further research is expected to take sampling with a greater number of research subjects. Double assimilation tests can be carried out to identify species of fungi so that the number and type of species are larger, varied and more specific. Sensitivity tests can be carried out with more antifungal drugs.
\end{abstract}

Keywords : antifungal, toenails

\section{ABSTRAK}

Kuku merupakan lempeng yang terbuat dari sel tanduk yang menutupi permukaan dorsal ujung jari tangan dan kaki. Jamur merupakan salah satu flora normal. Jamur yang termasuk dalam flora normal yang menginfeksi kuku adalah golongan dermatofita seperti Epidermaphyton floccosum. Tujuan penelitian ini untuk menentukan uji daya hambat obat antijamur dari golongan azol yaitu antijamur jenis obat griseofulvin, ketoconazole, intraconazole dan clotrimazole. Jenis penelitian yang digunakan adalah penelitian bersifat deskripif yang dilakukan secara laboratorik melalui observasional daya hambat antijamur yang diisolasi dari kuku kaki. Penelitian ini dilakukan di Laboratorium Mikrobiologi Politeknik Kesehatan Makassar dengan jumlah sampel sebanyak 10 sampel. Hasil penelitian menunjukkan bahwa uji daya hambat beberapa jenis antijamur tidak terjadi daya hambat pada jamur yang diisolasi dari kuku kaki oleh karena itu penelitian selanjutnya diharapkan melakukan pengambilan pengambilan sampel dengan jumlah subjek penelitian yang lebih banyak. Dapat dilakukan uji asimilasi ganda untuk mengidentifikasi spesies dari jamur sehingga jumlah dan jenis spesies lebih besar, bervariasi, dan lebih spesifik. Dapat dilakukan uji sensitivitas dengan obat antijamur yang lebih banyak.

Kata kunci : obat antijamur, kuku kaki 


\section{PENDAHULUAN}

Dalam manusia yang sehat, jaringan permukaan yaitu kulit dan selaput lendir (mukosa) mudah dihuni oleh berbagai spesies mikroba yang disebut sebagai flora normal (Todar K, 2012). Flora normal dibagi kepada dua kelompok yaitu flora tetap (resident flora) dan flora sementara (transient flora). Flora tetap terdiri dari mikroorganisma tertentu dan menetap pada bagian tubuh tertentu dan pada usia tertentu sedangkan flora sementara pula terdiri dari mikroorganisma nonpatogenik atau berpotensi patogen yang mendiami kulit atau selaput lender (mukosa) selama beberapa jam, hari atau minggu dan biasanya tidak akan menghasilkan penyakit (Jawetz E, dkk, 1980).

Kuku merupakan lempeng yang terbuat dari sel tanduk yang menutupi permukaan dorsal ujung jari tangan dan kaki (Haneke E, 2006). Jamur merupakan salah satu flora normal. Jamur yang termasuk dalam flora normal yang menginfeksi kuku adalah Candida albicansdari golongan yeast. Jamur lain yang sering berkolonisasi pada kuku adalah golongan dermatofita seperti Trichophyton rubrum, Trichophyton mentagrophytes, dan golongan nondermatofita seperti Aspergillus spp, Scopulariopsis brevicaulis dan sebagainya (Prasad G, Minakshi, 2007).

Jamur-jamur ini berkolonisasi pada kuku yang luka, kuku yang rusak atau kulit yang selalu lembab pada waktu yang lama dan orang-orang dengan imunitas tubuh yang rendah. Kolonisasi jamur pada kuku menyebabkan perubahan warna, perubahan struktur dan bentuk dan membawa berbagai jenis komplikasi pada kuku (Chander J, 2002).

Onikomikosis adalah infeksi kuku disebabkan oleh jamur dermatofita, nondermatofita dan yeast yang menyerang daerah superfisial kulit (epidermis). Dari semua kasus
Onikomikosis, $80 \%$ adalah infeksi pada kuku kaki dan hampir setengah kasus dari semua penyakit kuku adalah pada orang dewasa terutama pada orang tua (James A, dkk, 2016).

Angka kejadian Onikomikosis pada populasi di seluruh dunia sekitar 5\%. 20$40 \%$ dari kejadian tersebut merupakan Onychopathies dan $30 \%$ kejadian adalah kasus micotic cutaneous infection.Pada negara maju, angka kejadian Onikomikosis lebih tinggi sekitar 2-3\% sampai 13\%. Sedangkan negara Asia Tenggara, angka kejadian Onikomikosis lebih rendah. Ini dapat dilihat dari skala survei besar di Asia pada akhir 1990-an di mana prevalensi Onikomikosis lebih rendah di negara-negara tropis $(3,8 \%)$ daripada di negara-negara subtropis dan Negara-negara di zona beriklim $(18 \%)$ (Kaur R, dkk, 2008).

Di Indonesia, Onikomikosis merupakan salah satu masalah kesehatan dari segi diagnosis dan pengobatan. Untuk mengatasi hal ini, telah dilakukan dua penelitian retrospektif tentang kejadian Onikomikosis pada tahun 19971998 dan 2003 yang melibatkan 10 rumah sakit universitas negeri pada seluruh negara Indonesia. Hasil penelitian menunjukkan tahun 19971998 kejadian Onikomikosis sebanyak 3,5\% dan pada tahun 2003 kejadian Onikomikosis meningkat ke $4,7 \%$ di kota-kota besar (Bramono K, dkk, 2005).

Jamur atau fungi adalah salah satu sumber penyebab timbulnya penyakit. Infeksi oleh mikroba banyak terjadi apalagi di negara tropis seperti di Indonesia yang kelembabannya cukup tinggi. Hal ini menyebabkan baik bakteri maupun jamur tumbuh dan berkembang dengan cepat. Perkembangannya yang sangat cepat dan kemudahannya untuk tumbuh telah menuntut para penemu obat untuk mencari dan menemukan obat baru yang berfungsi sebagai antimikroba, karena infeksi oleh jamur 
sering dialami oleh manusia ataupun hewan.

Sementara itu, saat ini banyak mikroba yang telah resisten terhadap beberapa jenis antijamur. Tubuh kita merupakan tempat tinggal bagi sebagian jamur dan bakteri. Sebagian dari mikroba tersebut berguna bagi manusia, dan yang lain dalam kondisi tertentu dapat dengan cepat menggandakan diri dan akhirnya menyebabkan peradangan atau infeksi pada tubuh kita.

Antijamur sistemik golongan azol yang dapat digunakan sebagai obat antijamur salah satunya yaitu flukonazol dengan angka kesembuhan mencapai 97\%- $100 \%$ dalam dosis $300 \mathrm{mg}$ per minggu selama 2-3 minggu. Dalam penelitian sebelumnya membuktikan bahwa flukonazol dapat digunakan secara efektif untuk mengobati antijamur dengan efek samping yang rendah atau bahkan tidak ada. flukonazol pada kasus antijamur secara in vitro, didapatkan hasil sensitivitas $100 \%$ dari semua sampel. Dalam praktik klinik obat ini masih jarang diresepkan karena sediaanya yang hanya terdapat dalam bentuk sistemik. Sayangnya beberapa penelitian menunjukkan fakta bahwa telah terjadi resistensi obat untuk pengobatan penyakit jamur yang disebabkan baik dari faktor pejamu, obat, maupun dari jamur itu sendiri (Annisa Septiningrum, dkk. 2018).

Dari Journal of Fungi disebutkan bahwa angka kekambuhan dapat mencapai $80 \%$ dalam 2 tahun setelah pengobatan, sehingga untuk benar-benar sembuh harus dilakukan pengobatan secara menyeluruh, tekun, dan konsisten. Meningkatnya angka kekambuhan dapat menjadi suatu masalah di dunia kesehatan. Hal ini menyebabkan banyak obat antijamur digunakan secara luas di masyarakat yang akhirnya dapat meningkatkan angka resistensi terhadap obat antijamur (Annisa Septiningrum, dkk. 2018).

Infeksi dapat diobati dengan menggunakan antijamur. Antijamur adalah zat yang dihasilkan oleh suatu mikroba, terutama fungi (jamur), yang dapat menghambat atau dapat membasmi mikroba jenis lain, yang memiliki khasiat mematikan atau menghambat pertumbuhan kuman, sedangkan toksisitasnya bagi manusia relatif kecil (Sofa, 2004). Akan tetapi penggunaan antijamur secara besarbesaran untuk terapi dan profilaksis adalah faktor utama terjadinya resistensi. Banyaknya jamur yang sudah resisten terhadap antijamur tertentu menyebabkan pengobatan terhadap penyakit infeksi yang disebabkan oleh jamur menjadi lebih lama (Anonim, 2011).

Antifungi merupakan salah satu antijamur yang digunakan untuk menyembuhkan infeksi yang disebabkan oleh fungi atau jamur. Antifungi adalah aktivitas suatu senyawa yang dapat menghambat atau membunuh jamur tertentu, sehingga antifungi ini diharapkan dapat menyembuhkan suatu penyakit yang disebabkan oleh infeksi jamur. Beberapa antifungi yang digunakan oleh masyarakat umum adalah obat-obat hasil sintesis secara kimiawi, dari golongan azole.

\section{METODE}

\section{Desain, tempat, dan waktu}

Penelitian ini merupakan penelitian deskripif yang dilakukan secara laboratorik melalui observasional daya hambat antijamur yang diisolasi dari kuku kaki. Penelitian ini dilaksanakan pada tanggal 21 Mei s/d 20 Juni 2019. Lokasi pengambilan sampel dilakukan di Balocci Kecamatan Balocci Kabupaten Pangkep. Dan penelitian ini dilaksanakan di Balocci Kecamatan Balocci Kabupaten Pangkep. 


\section{Bahan dan alat}

Populasi dalam penelitian ini adalah semua kuku kaki petani yang terinfeksi jamur yang ada di Balocci. Sampel dalam penelitian ini adalah beberapa kuku kaki petani yang terinfeksi jamur sebanyak 10 sampel. Teknik pengambilan sampel dalam penelitian ini adalah dengan menggunakan purposive sampling. Alat yang digunakan dalam penelitian ini adalah Gelas kimia, gelas ukur, labu erlemeyer, pipet tetes, pipet ukur, timbangan, pengaduk, sendok tanduk, pinset, kertas timbang, cawan petri, ose, spoit, spirtus, objek gelass, deck glass, mikroskop, autoclave, jangka sorong. Dan bahan yang digunakan adalah media SDA, aquadest steril, cakram steril, antijamur griseofulvin, ketoconazole, intraconazole dan clotrimazole.

\section{Langkah-langkah penelitian}

1. Pra Analitik

a. Persiapan sampel

1)Identifikasi Jamur

Pemeriksaan ini menggunakan $\mathrm{KOH} 10 \%$ dan sediaan kerokan kuku kaki menggunakan pisau skalpel atau gelas objek kemudian diberi $\mathrm{KOH}$ $10 \%$ dan dilihat dibawah mikroskop.

2)Inokulasi Jamur

Kuku didesinfeksi dengan kapas alcohol $70 \%$, sampel diambil dari kuku yang digunting atau kerokan dari nail bed. Bila perlu dengan mengerok kuku bagian proksimal, sampelnya kemudian di inokulasi pada media SDA, diinkubasi pada suhu $20-25^{\circ} \mathrm{C}$ selama 3-4 hari hingga mendapatkan pertumbuhan yang normal. Selanjutnya Buat suspensi koloni jamur yaitu satu ose dalam 5 $\mathrm{ml} \mathrm{NaCl} \mathrm{0,9 \% .}$

3)Persiapan antijamur

Anti jamur yang digunakan adalah golongan azol yaitu griseofulvin, ketoconazole, intraconazole dan clotrimazole, masing-masing sebanyak 200 gr antijamur tersebut digerus dan dihaluskan terlebih dulu agar dapat diencerkan dengan menggunakan methanol $96 \%$ sebanyak $5 \mathrm{ml}$.

2. Analitik

Dituang suspensi jamur sebanyak $0,1 \mathrm{ml}$ kedalam $20 \mathrm{ml}$ media SDA yang sudah padat kemudian diratakan, diamkan pada suhu kamar selama 15 menit, kemudian cakram steril dicelupkan kedalam beberapa antijamur,diletakkan cakram diatas permukaan media SDA yang sudah diinokulasi jamur, inkubasi pada suhu 20-25 ${ }^{\circ} \mathrm{C}$ selama 7 hari.

3. Pasca Analitik

Parameter yang di ukur adalah aktivitas antijamur yang membentuk zona bening yang terjadi pada sekitar cakram dengan cara mengukur zona hambat yang terbentuk dengan menggunakan jangka sorong.

\section{Pengolahan dan analisa data}

Semua data yang peroleh dari hasil penelitian diolah secara deskriptif yaitu dengan menggambarkan hasil yang diperoleh dan selanjutnya dibuatkan tabel dan dijelaskan dengan narasi.

\section{HASIL}

Pada media Kode sampel 1,2,3,4,6,7, dan 10 menunjukkan bahwa terjadi pertumbuhan jamur Aspergillus flavus, pada kode sampel 5 dan 9 terjadi pertumbuhan jamur Rhizopus sp, sedangkan sampel 8 terjadi pertumbuhan jamur Epidermophyton floccosum.

Uji daya hambat pada jamur Epidermophyton floccosum pada anti jamur griseofulvin, ketoconazole dan intraconazole menunjukkan tidak terjadi daya hambat, dan pada anti jamur clotrimazole menunjukkan uji daya hambat $1 \mathrm{~mm}$. 


\section{PEMBAHASAN}

Jamur pada kuku adalah kondisi umum yang menyebabkan munculnya titik berwarna putih atau kuning di bagian bawah ujungnya jika infeksi jamur kuku menjalar semakin dalam. Kondisi yang juga memiliki nama lain onikomikosis ini dapat menyerang lebih dari satu kuku, namun jarang sekali menyerang seluruh kuku. Pada kasus jamur kuku parah dapat terjadi kerusakan permanen pada kuku serta menimbulkan rasa sakit.

Antifungi merupakan salah satu antibiotika yang digunakan untuk menyembuhkan infeksi yang disebabkan oleh fungi atau jamur. Antifungi adalah aktivitas suatu senyawa yang dapat menghambat atau membunuh jamur tertentu, sehingga antifungi ini diharapkan dapat menyembuhkan suatu penyakit yang disebabkan oleh infeksi jamur. Beberapa antifungi yang digunakan oleh masyarakat umum adalah obat-obat hasil sintesis secara kimiawi, misalnya Nistantin, Ketoconazole, Fluconazole yang mungkin lebih mahal dan sulit disintesis.

Anti jamur golongan azol merupakan senyawa sintetik dengan aktivitas spectrum yang luas, yang diklasifikasi berdasarkan kandungan atom nitrogennya. Kerja antijamur secara tidak langsung (golongan azol) adalah menganggu biosintesis ergosterol dengan cara menganggu demetilasi ergosterol pada jalur sitokrom P450 (demetilasi precursor ergosterol).

Pada umumnya golongan azol bekerja menghambat biosintesis ergosterol yang merupakan sterol utama untuk mempertahankan integritas membrane sel jamur. Bekerja dengan cara menginhibisi enzim sitokrom P450, C-14- $\alpha$-demethylase yang bertanggung jawab merubah lanosterol menjadi ergosterol, hal ini mengakibatkan dinding sel jamur menjadi permeable dan terjadi penghancuran jamur.

Pengujian aktivitas antijamur sama artinya dengan menentukan kerentanan jamur terhadap suatu zat antijamur. Beberapa faktor yang mempengaruhi aktivitas antijamur in vitro antara lain adalah $\mathrm{pH}$ lingkungan, komponen media, stabilitas zat antijamur, ukuran inokulum, masa inkubasi dan aktivitas metabolisme mikroorganisme.

Metode difusi agar dari prosedur Kirby-Bauer, sering digunakan untuk mengetahui sensitivitas mikroba. Prinsip dari metode ini adalah penghambatan terhadap pertumbuhan mikroba, yaitu zona hambat akan terlihat sebagai daerah jernih di sekitar sumuran yang mengandung zat antimikrobia. Luas zona hambat pertumbuhan mikrobia menunjukkan sensitifitasnya terhadap zat antimikrobia yang digunakan. Selanjutnya, dikatakan bahwa semakin besar luas zona hambat yang terbentuk berarti mikrobia tersebut semakin sensitif. Zona hambat merupakan tempat mikrobia terhambat pertumbuhannya akibat senyawa antimikrobia.

Dalam penelitian ini menggunakan obat anti jamur golongan azol yaitu griseofulvin, ketoconazole, intraconazole dan clotrimazole. Griseofulvin adalah obat anti jamur yang efektif terhadap berbagai jenis dermatofit seperti Epidermophyton floccosum. Ketoconazole adalah obat anti jamur untuk mengobati infeksi jamur tertentu pada tubuh, ketoconazole termasuk golongan azol yang berkerja menghentikan pertumbuhan jamur. Intraconazole adalah obat untuk mengatasi infeksi jamur dengan cara menghambat pertumbuhan sel jamur. Sedangkan clotrimazole adalah obat antijamur yang berfungsi untuk mengobati infeksi jamur pada kulit (tinea pedis, kurap, panu) dengan cara 
menghambat pertumbuhan jamur penyebab infeksi.

Berdasarkan hasil penelitian menunjukkan bahwa uji daya hambat pada jamur Epidermophyton floccosum pada anti jamur griseofulvin, ketoconazole dan intraconazole menunjukkan tidak terjadi daya hambat, dan pada anti jamur clotrimazole menunjukkan uji daya hambat $1 \mathrm{~mm}$.

Penelitian sebelumnya menunjukkan bahwa hasil uji kepekaan 4 obat anti jamur yaitu griseofulvin, ketoconazole, intraconazole, dan terbinafin terhadap spesies dermatofit yauti griseofulvin 23,3 \% sensitive terhadap ketokonasol, 16,7 \% sensitive terhadap intrakonasol, dan $20 \%$ sensitive terhadap terbinafin (Ratri et al, 2015).

Dengan melihat hasil penelitian yang telah dilakukan menunjukkan bahwa dari ketiga antijamur yaitu golongan azol griseofulvin, ketoconazole, dan intraconazol tidak terjadi daya hambat sedangkan antijamur golongan azol clotrimazole menunjukkan uji daya hambat sebesar 1 $\mathrm{mm}$. hal ini disebabkan oleh jumlah isolat yang diperiksa, sehingga pengamatan KHM kurang maksimal, dan dapat pula terjadi akibat terinfeksi oleh spesies dermatofit yang sudah resisten pada obat antijamur, tetapi hasil penelitian yang menunjukkan kemungkinan resistensi yang dilakukan secara in vitro masih belum dihubungkan dengan keberhasilan terapi secara klinis.

Adanya kemungkinan resistensi terhadap spesies dermatofit yang diteliti ini menjadi suatu kekhawatiran dan membuat kita sebagai klinisi harus lebih berhati-hati dalam pemberian dosis obat antijamur. Penggunaan obat antijamur secara luas tanpa resep dokter juga dapat menyebabkan resistensi, selain itu penggunaan yang kurang adekuat dan pemberian berulang obat antijamur juga meningkatkan kemungkinan resistensi, seperti yang pernah dilaporkan oleh Al-Refai (2007) pada kasus tinea kapitis yang mendapatkan pengobatan berulang akan membutuhkan waktu penyembuhan yang lebih panjang Ini memungkinkan terdapat mekanisme resistensi yang berbeda-beda terhadap antijamur golongan azol. Beberapa mekanisme ini serupa dengan resistensi antibakteri. Kadang kejadian resistensi terhadap sebuah obat golongan azol menyebabkan resistensi silang terhadap obat-obat golongan azol lainnya. Namun kadang resistensi ini bersifat spesifik untuk satu obat saja. Keadaan ini tergantung dari spesifisitas mekanisme resistensinya (misalnya afinitas enzim target atau efflux pump untuk struktur molekular tertentu).

Beberapa mekanisme resistensi terhadap antijamur golongan azol antara lain: 1) Overproduksi enzim target, sehingga obat tidak menghambat reaksi biokimia secara lengkap, 2) Perubahan pada target obat sehingga obat tidak dapat berikatan dengan target, 3) Obat dipompa keluar oleh efflux pump, 4) Jalan masuk obat terhalang pada tingkat membran sel atau dinding sel, 5) Sel mempunyai jalur bypass yang dapat mengkompensasi hilangnya fungsi penghambatan akibat aktivitas obat, 6) Beberapa "enzim" jamur yang mengubah obat inaktif menjadi bentuk aktif terhambat, 7) Sel mensekresi beberapa enzim ke medium ekstraseluler, yang mendegradasi obat.

\section{KESIMPULAN}

Berdasarkan hasil penelitian terhadap 10 media SDA menunjukkan bahwa uji daya hambat beberapa jenis antijamur tidak terjadi daya hambat pada jamur yang diisolasi dari kuku kaki.

\section{SARAN}


1. Penelitian selanjutnya diharapkan melakukan pengambilan pengambilan sampel dengan jumlah subjek penelitian yang lebih banyak. Dapat dilakukan uji asimilasi ganda untuk mengidentifikasi spesies dari jamur sehingga jumlah dan jenis spesies lebih besar, bervariasi, dan lebih spesifik. Dapat dilakukan uji sensitivitas dengan obat antijamur yang lebih banyak.

2. Disarankan kepada masyarakat untuk dapat menggunakan antijamur yang efektif sehingga menghindari reisten obat anti jamur.

\section{UCAPAN TERIMA KASIH}

Penulis mengucapkan banyak terima kasih kepada seluruh pihak Jurusan Analis Kesehatan yang telah membantu dalam proses penelitian ini.

\section{DAFTAR PUSTAKA}

Annisa Septiningrum., Muslimin., V Rizke Ciptaningtyas. 2018. Uji Beda Sensivitas Jamur Malassezia sp terhadap flukonazol dan mikonazol secara in vitro. Universitas Diponogoro. Semarang.

Anonim, 2011. Efek Samping Fungisida Golongan Azol. http://blajartani.blogspot.com/20 11_04_01_archive.html. Diakses tanggal 20 Januari 2019.

Bramono K, Budimulja U. Epidemiology of Onychomycosis in Indonesia : Data Obtained from Three Individual Studies. Jpn J Med Mycol. 2005: 46(3): 171-176.

Chander J. Textbook of Medical Mycology: Dermatophytoses. 2nd edition. New Delhi: Mehta publishers; 2002.

Haneke E. Surgical Anatomy of the Nail Apparatus. Dermatologic Clinics. 2006 : 24(3): 291-296.
James A, Mark O, Nyong A. Fungal Nail Infections: Spectrum of Aetiologic Agents and Pattern of Lesions. Journal of Microbiology and Infectious Diseases. 2016: 6(01): 23-27.

Jawetz E, Melnick J.L, Adelberg E.A. Normal Microbial Flora of the Human Body. In : eview of Medical Microbiology : $14^{\text {th }}$ edition. California: Lange Medical Publications; 1980. 176

Jawetz, E, J. melnick, el al. 2006. Mikrobiologi Kedokteran. Jakarta. EGC

Kaur R, Kashyap B, Bhalla P. Onychomycosis-Epidemiology, Diagnosis and Management. Indian Journal of Medical Microbiology. 2008: 26(2): 108116.

Prasad G, Minakshi. Immunology and Medical Microbiology : Normal Microbial Flora of Human Body and Host Parasite Relationship. 2007 Aug 02: 1-23

Todar K. The Normal Bacterial Flora of Humans. Online Textbook of Bacteriology. 2012. Available from:

www.textbookofbacteriology.net 
Tabel 01. Interpretasi Hasil Pemeriksaan Daya Hambat

\begin{tabular}{ccc}
\hline No & Daerah Hambatan & Ketentuan \\
\hline 1 & $>20 \mathrm{~mm}$ & Sangat Kuat \\
\hline 2 & $10-20 \mathrm{~mm}$ & Kuat \\
\hline 3 & $5-10 \mathrm{~mm}$ & Sedang \\
\hline 4 & $<5 \mathrm{~mm}$ & Lemah \\
\hline
\end{tabular}

Tabel 02. Hasil Pertumbuhan Pada Media Sabouraud Dextrose Agar

\begin{tabular}{|c|c|c|}
\hline \multirow[b]{2}{*}{ Sampel } & \multicolumn{2}{|c|}{ Hasil Identifikasi Kultur } \\
\hline & $\begin{array}{l}\text { Pertumbuhan } \\
\text { Jamur }\end{array}$ & Mikroskopis \\
\hline $\begin{array}{l}\text { Control } \\
\text { Media } \\
\end{array}$ & Tidak ditemukan & (-) tidak ditemukan \\
\hline $\begin{array}{l}\text { Control } \\
\text { Ruang }\end{array}$ & Hitam & (+) spora, Aspergillus sp \\
\hline 1 & Hitam, Putih & (+) spora, Aspergillus sp \\
\hline 2 & $\begin{array}{l}\text { Hitam, Putih, } \\
\text { Kekuningan }\end{array}$ & (+) spora, Aspergillus sp \\
\hline 3 & Hitam, Putih & (+) spora, Aspergillus sp \\
\hline 4 & Hitam, Kehijauan, Putih & (+) hifa, Aspergillus $s p$ \\
\hline 5 & Hitam, Putih & (+) spora, Rhizopus sp \\
\hline 6 & Hitam, Putih & (+) hifa, Aspergillus $s p$ \\
\hline 7 & Hitam, Putih & (+) spora, Aspergillus sp \\
\hline 8 & Hitam, Putih & $\begin{array}{l}\text { (+) hifa, Epidermophton } \\
\text { floccosum }\end{array}$ \\
\hline 9 & $\begin{array}{c}\text { Hitam, Putih, } \\
\text { Kekuningan }\end{array}$ & (+) hifa, Rhizopus sp \\
\hline 10 & Kehijauan, Putih & (+) hifa, Aspergillus $s p$ \\
\hline
\end{tabular}

Sumber : Data Primer, 2019

Tabel 03. Hasil Uji Daya Hambat Antijamur

\begin{tabular}{ccclc}
\hline Jamur & \multicolumn{4}{c}{ Uji Daya Hambat Obat Anti Jamur $(\mathrm{mm})$} \\
\hline \multirow{2}{*}{$\begin{array}{c}\text { Epidermophyton } \\
\text { floccosum }\end{array}$} & Griseofulvin & Ketoconazole & Intraconazole & Clotrimazole \\
\cline { 2 - 5 } & $\begin{array}{c}\text { Tidak } \\
\text { terjadi }\end{array}$ & Tidak terjadi & Tidak terjadi & 1 \\
& $\begin{array}{c}\text { Daya } \\
\text { hambat }\end{array}$ & Daya hambat & Daya hambat & \\
\hline
\end{tabular}

Sumber : Data Primer, 2019 